\title{
ANALISIS FENOMENA PERILAKU PENYIMPANGAN SEKSUAL (LGBT) DI INDONESIA DALAM PANDANGAN HUKUM ASASI MANUSIA
}

\author{
Hawu Yosafak, Galih Puji Mulyono
}

\author{
Fakultas Hukum Universitas Merdeka Malang \\ Jl. Terusan Dieng No. 62-64; Malang; 65146; Indonesia; (0341) 580161 \\ Email: hawuyosafat@gmail.com,galihpujimulyono@unmer.ac.id
}

\begin{abstract}
The existence of LGBT people in Indonesia is still seen as negative and unfairly treated, both by the community, the government, even in the eyes of the law. This is clearly contrary to Human Rights, as well as contrary to Pancasila, which in essence upholds justice and human rights. The formulation of the problem in this writing is how the phenomenon of LGBT through the concept of human rights, and how the legal perspective on LGBT people. The concept of human rights does not look at sexual orientation and human gender identity. Appreciation for gender continues to obtain basic human rights in their entirety regardless of their abnormalities. LGBT people, although deviating from social behavior and contradicting the norms of society, are still obliged and cannot be revoked from their basic rights. In the view of human rights, LGBT people must be protected psychologically to return to being fully societies not to behave in a deviant manner. In the legal sphere LGBT people still experience various forms of discrimination. These efforts can be carried out using two approaches, namely preventive and remedial.
\end{abstract}

Key words: Sexual Deviation, LGBT, Human Rights.

\begin{abstract}
ABSTRAK
Keberadaan kaum LGBT di Indonesia, masih dipandang negatif dan diperlakukan tidak adil, baik oleh masyarakat, pemerintah, bahkan di mata hukum.. Hal ini jelas bertentangan dengan Hak Asasi Manusia, serta bertentangan dengan Pancasila, yang pada hakikatnya menjunjung tinggi keadilan dan Hak Asasi Manusia. Rumusan masalah dalam penulisan ini adalah bagaimana fenomena LGBT melalui konsep HAM, dan bagaimana prespektif hukum terhadap kaum LGBT. Konsep HAM tidak memandang orientasi seksual dan identitas gender manusia. Kaum LGBT walaupun menyimpang dari perilaku sosial dan bertentangan dengan norma masyarakat kaum LGBT masih wajib dan tidak boleh dicabut hak dasarnya, dalam pandangan HAM kaum LGBT mendapatkan perlindungan untuk di perbaiki secara psikologis supaya kembali menjadi masyarakat seutuhnya tidak berperilaku menyimpang. Dalam ranah hukum kaum LGBT masih mengalami berbagai bentuk diskriminasi. Upaya tersebut bisa dilaksanakan menggunakan dua pendekatan yaitu preventif dan remedial.
\end{abstract}

Kata Kunci: Penyimpangan Seksual, LGBT, Hak Asasi Manusia.

\section{PENDAHULUAN}

LGBT adalah istilah yang dipakai untuk mewakili mereka yang tergolong dalam kelompok lesbian, gay, biseksual dan transgender. Meski demikian, istilah ini dibuat untuk mewakili berbagai budaya berdasarkan perbedaan identitas seksualitas dan gender. Sehingga istilah ini pun 
digunakan untuk mewakili orang non heteroseksual dan kelompok cisgender lainnya selain kelompok lesbian, gay, biseksual dan transgender ${ }^{1}$. Istilah ini digunakan semenjak tahun 1990 untuk menggantikan istilah-istilah sebelumnya yang dianggap tidak mewakili seluruh kelompok identitas seksual, maupun istilah yang dianggap memiliki konotasi negatif, seperti istilah "gender ketiga" yang dipakai sejak kurang lebih tahun 1860, juga istilah homoseksual dan homofil yang dipakai sekitar 1950 dan 1960, dan yang terakhir istilah kelompok gay yang sempit.

Kelompok LGBT, dan kelompok interseks lainnnya, yaitu mereka yang lahir dengan karakteristik seksual yang tidak sesuai dengan tipikal ciri binary laki-laki maupun perempuan ${ }^{2}$, cenderung mendapat perlakuan diskriminatif. Di berbagai daerah, banyak orang mengalami kekerasan karena orientasi seksual dan identitas gender mereka. Dalam banyak kasus, persepsi terhadap homoseksualitas dan transgender saja dapat membahayakan seseorang. Kekerasan yang dilakukan meliputi, namun tidak terbatas pada pembunuhan, pemerkosaan, penahanan tanpa dasar hukum, pembatasan hak-hak, dan diskriminasi di bidang pekerjaan, kesehatan, serta pendidikan ${ }^{3}$. Tidak terbatas pada aksi kekerasan, dalam beberapa kasus pemerintah pun turut berlaku tidak adil dengan menetapkan hukum yang diskriminatif terhadap kaum LGBT dan interseks lainnya.

Terutama di Indonesia, kaum LGBT masih dipandang negatif dan diperlakukan tidak adil, baik oleh masyarakat, pemerintah, bahkan di mata hukum. Pergerakan LGBT yang sudah ada di Indonesia sejak 1969 dengan adanya Asosiasi Wadam Djakarta, dan sejak didirikannya organisasi LGBT secara terbuka, yaitu Lambda pada 1 Maret 1982, seringkali mendapat hambatan dalam menjalankan kegiatannya. Pada bulan September 1999, ada ancaman dari Front Pembela Islam (FPI) Surakarta untuk menyerang Pertemuan Nasional JLGI di Solo, sehingga kegiatan tersebut dibatalkan. Pada bulan November 2000, kampanye HIV/AIDS yang diorganisir oleh organisasi LGBT Indonesia di Kaliurang diserang oleh kelompok fundamentalis islam tertentu, sehingga kegiatan terpaksa dibubarkan ${ }^{4}$.

Tidak hanya itu, pada tahun 2002, provinsi Aceh diberikan hak istimewa untuk menerapkan hukum syariat islam, yang

\footnotetext{
Swain, Keith W. 21 Juni 2007. "Gay Pride Needs New Direction". Denver Post. Diakses tanggal 12-01-2018

"Free \& Equal Campaign Fact Sheet: Intersex". United Nations Office of the High Commissioner for Human Rights. 2015. Diakses tanggal 13-01-2018

3 "Discriminatory laws and practices and acts of violence against individuals based on their sexual orientation and gender identity”. United Nations High Commissioner for Human Rights. 2011. Halaman 3. Diakses tanggal 13-10-2018

4 Yulianti Muthmainnah. 2016. “LGBT Human Rights in National Policies”. Indonesian Feminist Journal. Vol. 4, No. 1, hlm. 16.
} 
konsekuensi dari pelaksanaannya adalah hukuman cambuk terhadap pasangan gay di Aceh pada 23 Mei 2017. Dua pria yang ditangkap oleh warga lantaran dituding melakukan hubungan seks sesama jenis pada 28 Maret 2017 lalu, dihukum masing-masing 85 kali cambuk oleh majelis hakim Mahkamah Syariah Kota Banda Aceh. Mereka dinyatakan bersalah karena melanggar "Jarimah Liwat". Berdasarkan Pasal 63 ayat 1 Qanun Nomor 6 Tahun 2014 tentang Hukum Jinayat, ancaman hukumannya masing-masing 100 kali cambuk atau denda paling banyak 1.000 gram emas murni atau penjara paling lama 100 bulan $^{5}$. Di Palembang, Sumatera Selatan, menjadi gay/homoseksual dapat dihukum dengan hukuman penjara dan denda ${ }^{6}$.

Majelis Ulama Indonesia (MUI) mengeluarkan fatwa yang menyerukan berbagai hukuman, dari cambuk hingga hukuman mati, untuk para kaum homoseksual pada 3 Maret 2015. Hasanuddin A.F., Ketua Komisi Fatwa MUI, mengatakan fatwa itu dikeluarkan karena penyimpangan seksual meningkat, bahkan telah menyusup ke sekolah-sekolah. Hasanuddin mengatakan penyimpangan seksual menyakiti moral nasional. Dia pun meminta pemerintah mendirikan pusat rehabilitasi untuk "mengobati" orang LGBTI (lesbian, gay, bisexual, transgender, and intersex) dan membasmi homoseksualitas di negara ini ${ }^{7}$.

Beberapa peristiwa dan fenomena diatas hanya bagian kecil dari ketidakadilan yang dialami kelompok interseks dan kelompok LGBT di Indonesia. Pandangan negatif masyarakat terhadap kelompok LGBT, baik karena pengaruh agama, maupun adat istiadat lainnya, juga semakin memperburuk kondisi kelompok LGBT di Indonesia, yang selain harus hidup dibawah kekerasan struktural, juga harus berurusan dengan cibiran dan perkataan miring masyarakat. Lalu bagaimana dengan HAM yang mereka miliki? Satu pandangan yang dimiliki oleh mereka yang menolak LGBT, adalah bahwasannya mereka menilai LGBT sebagai bentuk penyimpangan, dan tidak masuk dalam konsepsi $\mathrm{HAM}^{8}$. Oleh karena itu pandangan tersebut memiliki arti, bahwa kebebasan untuk memilih pasangan dan orientasi seksual bukanlah bagian dari HAM dan pelanggaran dari HAM.

Kebebasan memilih pasangan dan orientasi seksual menjadi landasan rumusan masalah dalam penulisan ini yaitu bagaimana konsep

http://nasional.kompas.com/read/2017/05/18/12310041/icjr.nilai.hukum.cambuk.pasangan.lgbt.di.aceh. diskriminatif. Diakses pada tanggal 13-01-2018

6 "Special Report: Indonesia - Exchanging pluralism for an Islamic state".http://pancasilaislam. blogspot.sg/2012/10/special-report-indonesia-exchanging.html. Diakses pada tanggal 13-01-2018

7 https://nasional.tempo.co/read/650564/mui-keluarkan-fatwa-hukum-mati-kaum-homoseksual. Diakses pada tanggal 13-01-2018

8 Meilanny Budiarti Santoso. 2016. "LGBT dalam perspektif Hak Asasi Manusia"Staf Pengajar Departemen Kesejahteraan Sosial - Universitas Padjadjaran. Vol. 6 No. 2 hlm. 221. 
HAM dan kaitannya dengan LGBT dan bagaimana perlindungan hukum terkait kaum LBGT di Indonesia, sehingga hak-hak setiap manusia, termasuk kaum LGBT dapat terlaksana, dan menanamkan kesadaran akan pentingnya menghormati hak sesama, termasuk hak kaum LGBT.

\section{PEMBAHASAN}

LGBT Dalam Pandangan Konsep Hak Asasi Manusia Berdasarkan Kaidah Pancasila

Hak Asasi Manusia biasanya dianggap sebagai hak yang dimiliki setiap manusia, yang melekat atau inheren padanya karena dia adalah manusia. Dalam Mukadimah Kovenan Internasional Hak Sipil dan Politik tahun 1966 dicanangkan: "Hak-hak ini berasal dari harkat dan martabat yang melekat pada manusia. Hak ini sangat mendasar atau asasi sifatnya, yang mutlak diperlukan agar manusia dapat berkembang sesuai dengan bakat, cita-cita serta martabatnya. Hak ini juga dianggap universal, artinya dimiliki semua manusia tanpa perbedaan berdasarkan bangsa, ras, agama, atau gender ${ }^{9}$. Hal tersebut sesuai dengan kaidah norma dasar bangsa Indonesia sebagai landasan filosofi bangsa.

Hak Asasi Manusia dirumuskan dalam Pancasila, dalam sila kedua, Kemanusiaan Yang Adil dan Beradab. Sila ini pada hakikatnya menghendaki terlaksananya human values, dalam arti pengakuan dignity of man, human rights, dan human freedom. Tiap-tiap orang diperlakukan secara pantas, tidak boleh disiksa dan dihukum secara ganas, dihina atau diperlakukan secara melampaui batas $^{10}$. Hak Asasi Manusia menurut Sila kelima, Keadilan Sosial Bagi Seluruh Rakyat Indonesia, adalah terlaksananya kesejahteraan umum bagi seluruh anggota masyarakat. Dengan ini dimaksudkan adanya keadilan bagi sesama anggota masyarakat ${ }^{11}$. Hak Asasi Manusia menurut kedua Sila tersebut pada hakikatnya menekankan adanya keadilan. Bahwa setiap orang secara individu memiliki hak-hak yang setara, dan dalam kehidupan sosial, setiap orang diperlakukan secara adil, tanpa adanya ketimpangan maupun diskriminasi dalam bentuk apapun dan karena alasan apapun.

Tentunya, dengan adanya hak muncul juga kewajiban. Dengan adanya Hak Asasi Manusia muncul juga kewajiban untuk menghormati dan tidak melanggar hak tersebut. Dalam menjalankan hak-haknya seseorang harus juga memperhatikan hak-hak orang lain, sehingga dalam menjalankan hakhaknya, orang tersebut tidak menyalahi atau melanggar hak orang lain. Karena itulah dalam pelaksanaannya Hak Asasi Manusia dalam keadaan tertentu juga perlu

9 Budiarjo, Miriam. 2008. “Dasar-Dasar Ilmu Politik”. Jakarta. Gramedia Pustaka Utama. Halaman 212

10 Wahidin, Samsul. 2015. "Dasar-Dasar Pendidikan Pancasila dan Pendidikan Kewarganegaraan”. Yogyakarta. Pustaka Pelajar. Hlm. 14.

11 Ibid. hlm. 17. 
pembatasan. Namun pembatasan tersebut tidak berarti penghilangan atau pelarangan suatu hak untuk dijalankan. Terlaksananya Hak akan keadilan dan kebebasan yang disertai dengan kewajiban untuk menjaganya adalah kunci menuju kesejahteraan. Hal ini memiliki signifikansi yang tinggi terkait permasalahan kelompok LGBT di Indonesia.

Mengenai hakikat LGBT itu sendiri, muncul juga banyak pandangan mengenai apakah LGBT merupakan sesuatu yang dapat dirubah, atau sesuatu yang dibawa seseorang sejak lahir. Berbagai jawaban muncul terkait seberapa murni faktor biologis mempengaruhi orientasi seksual dan gender seseorang. Riset terhadap basis biologis dari orientasi seksual mencakup berbagai bidang seperti struktur otak, kromosom dan epigenetik namun jawaban jelas yang nampak adalah: Ya. Faktor biologis memiliki peran, dan Tidak. Faktor biologis bukan satu-satunya faktor yang berperan. Ada juga faktor psikologis dan faktor sosial yang berperan. Charles W. Socarides berpendapat bahwa homoseksualitas adalah adaptasi neurotik, dan karenanya dapat diubah ${ }^{12}$.

Mengacu pada pemaparan diatas, dapat disimpulkan bahwa Hak Asasi Manusia adalah sesuatu yang tidak dapat dipisahkan dari pemilik hak tersebut, apapun alasannya. Semuanya semata-mata karena keberadaan seseorang sebagai manusia. Perbedaan ciri fisik, kepercayaan dan identitas tidak dapat merubah kenyataan bahwa seseorang terlahir sebagai manusia, dan karenanya membawa bersamanya Hak Asasi miliknya. Hal ini juga berlaku untuk golongan LGBT, dan golongan interseksual lainnya. Mengikuti pandangan umum bahwa golongan LGBT menyalahi kodrat manusiawi yang seharusnya, (dalam hal ini sebagai seorang laki-laki atau perempuan, dan laki-laki berpasangan dengan perempuan dan sebaliknya), tidak merubah kenyataan bahwa mereka terlahir sebagai manusia, yang karena kenyataan itu sendiri menjadikan mereka memiliki Hak Asasi yang tidak dapat dilanggar atau dicabut. Terlepas dari seberapa besar faktor biologis, psikologis dan sosial berperan dalam menentukan orientasi seksual, selama seorang manusia lahir sebagai seorang manusia, dia memiliki Hak Asasi Manusia.

Menanggapi pandangan bahwa homoseksualitas adalah sesuatu yang harus disembuhkan atau direhabilitasi, maka mengacu pada prinsip kebebasan, dimana seseorang berhak menentukan siapa dirinya, keputusan untuk mencoba jalur rehabilitasi, apapun bentuknya, semuanya menjadi keputusan dari mereka golongan LGBT. Bukanlah hak pihak lain maupun pemerintah untuk menentukan, dan memaksakan hal

12 https://en.wikipedia.org/wiki/Charles_W._Socarides. Diakses pada tanggal 13-01-2018 
tersebut dalam bentuk apapun. Dan mengenai penyembuhan itu sendiri, terlepas dari berhasil tidaknya proses tersebut, maka kembali pada poin pertama, bahwa tidak ada yang dapat menggantikan kenyataan bahwa seseorang dilahirkan sebagai manusia yang memiliki Hak Asasi, yang tidak dapat dicabut karena apapun.

Diskriminasi terhadap kaum LGBT dalam bidang apapun, serta perlakuan tidak sepantasnya terhadap mereka, baik berupa kekerasan fisik maupun struktural, jelas merupakan pelanggaran terhadap Hak Asasi Manusia, apapun alasannya. Adalah sebuah kewajiban bagi siapapun untuk menghormati hak sesamanya, termasuk kaum LGBT. Karenanya demi mewujudkan keadilan sebagaimana dicita-citakan dalam Pancasila, sudah seharusnya pemerintah dengan kerangka hukumnya lebih memperhatikan pemenuhan serta perlindungan hak-hak dari golongan LGBT dari segala macam bentuk diskriminasi. Sebagaimana hak-hak dari golongan masyarakat lainnya dilindungi dan dipenuhi.

Permasalahan selanjutnya yang perlu diperhatikan adalah bagaimana mekanisme hukum di Indonesia saat ini terkait dengan hak-hak golongan LGBT di Indonesia. Sebagai perpanjangan tangan dari Pancasila dan HAM, hukum ada untuk mewujudkan keadilan bagi siapa saja. Adanya butir-butir hukum yang melemahkan masyarakat golongan manapun secara tidak adil menandakan kegagalan dari hukum itu sendiri dalam mewujudkan keadilan.

\section{Perlindungan Hukum Kaum LGBT di Indonesia}

Reaksi penentangan yang kuat terhadap kaum LGBT yang dianggap sebagai ancaman bagi bangsa mungkinmengejutkan, namun ia tak terjadi begitu saja. Khusus untuk isu homoseksualitas, Boellstorff, pada 2007, menyatakan bahwa,"Saat bangsa dianggap terancam terdisintegrasi, upaya dari orangorang yang berada di luar norma untuk masuk ke dalam masyarakat sipil bisa dianggap sebagai ancaman untuk bangsa itu sendiri."13

Pandangan kaum LGBT di Indonesia dalam hal ini berkaitan hukum nasionalnya dalam arti luas tidak memberi dukungan bagi kelompok LGBT walaupun homoseksualitas sendiri tidak ditetapkan sebagai tindak pidana. Baik perkawinan maupun adopsi oleh orang LGBT tidak diperkenankan. Tidak ada undang-undang anti-diskriminasi yang secara tegas berkaitan dengan orientasi seksual atau identitas gender. Hukum Indonesia hanya mengakui keberadaan gender laki-laki dan perempuan saja, sehingga orang transgender yang tidak memilih untuk menjalani operasi perubahan kelamin, dapat mengalami masalah dalam pengurusan dokumen identitas dan hal lain yang terkait. Sejumlah Perda melarang

13 Boellstorff, A Coincidence of Desires, hlm. 176. 
homoseksualitas sebagai tindak pidana karena dipandang sebagai perbuatan yang tidak bermoral, meskipun empat dari lima Perda yang terkait tidak secara tegas mengatur hukumannya ${ }^{14}$.Sebagai penjabaran dari pernyataan tersebut, berikut adalah undangundang yang paling berkenaan dengan konteks seksualitas.

1. Pasal 292 KUHP yang berbunyi: "Orang dewasa yang melakukan perbuatan cabul dengan orang lain sesama kelamin, yang diketahuinya atau sepatutnya harus diduganya belum dewasa, diancam dengan pidana penjara paling lama lima tahun". Pasal ini memang melarang aktivitas seksual antara sesama jenis, namun subyek hukum yang diatur dalam pasal tersebut adalah orang yang belum dewasa. Dalam pasal tersebut juga tidak ada unsur mengkriminalisasi seseorang murni semata-mata karena orientasi seksualnya, melainkan karena perbuatan cabul orang tersebut. Sehingga masih dimungkinkan bagi seseorang untuk terbuka mengenai seksualitasnya, tanpa ada resiko kriminalisasi terhadapnya. Terdapat upaya untuk memperluas cakupan pasal ini agar juga mengatur kaum LGBT secara lebih luas, tidak terbatas pada subjek dibawah umur saja. Upaya juga dilakukan untuk memperluas cakupan pasal 284 dan pasal 285 untuk mencakup kelompok LGBT. upaya tersebut dilancarkan dalam bentuk permohonan uji materi terhadap ketiga pasal KUHP tersebut, yang kemudian ditolak oleh MK melalui Putusan MK Nomor 46/PUU-XIV/2016. Perlu diketahui bahwa meskipun terlihat bahwa ada kekosongan hukum terkait perbuatan zinah antar sesama jenis, dalam RUU KUHP, larangan terhadap perbuatan zinah antar sesama jenis akan turut disertakan.

2. Pasal 1 Undang-Undang Nomor 1 Tahun 1974 tentang Perkawinan yang berbunyi: "Perkawinan adalah ikatan lahir batin antara seorang pria dan seorang wanita sebagai suami istri dengan tujuan membentuk keluarga atau rumah tangga yang bahagia dan kekal berdasarkan Ketuhanan Yang Maha Esa". Dalam rumusannya pasal ini jelas mendefinisikan subyek hukum dari sebuah perbuatan perkawinan, yaitu seorang pria dan seorang wanita, sehingga mengacu pada rumusan tersebut, perkawinan antar sesama pria atau sesama wanita tidak diperbolehkan. Hal ini dapat dilihat sebagai pembatasan terhadap hak-hak kaum LGBT, karena secara hukum tidak diberikan kemampuan untuk berkeluarga sesuai dengan preferensi mereka.

14 Dédé Oetomo dan Khanis Suvianita. 2014. "Hidup sebagai LGBT di Asia: Laporan Nasional Indonesia". Komunitas Nasional LGBT Indonesia. hlm. 9. 
3. Undang-Undang Nomor 23 Tahun 2006, tentang Administrasi Kependudukan yang ketentuan mengenai perkawinan yang sah dalam undang-undang tersebut mengikuti ketentuan Undang Undang Nomor 1 Tahun 1974 tentang Perkawinan, jelas tidak mengakomodasi kebutuhan kaum LGBT. Pasal 64 undang-undang tersebut juga menetapkan dua jenis kelamin, lakilaki dan perempuan. Hal ini jelas mempersulit kelompok transgender dan mereka yang tidak mengidentifikasi diri dengan dua jenis kelamin tersebut, untuk melakukan pengurusan Kartu Tanda Penduduk, yang berimbas pada kesulitan dalam melakukan perbuatan administratif lainnya yang membutuhkan Kartu Tanda Penduduk. Undang-Undang Nomor 44 Tahun 2008 tentang Pornografi dalam penjelasannya menafsirkan istilah "Persenggamaan yang menyimpang" sebagai persenggamaan atau aktivitas seksual lainnya dengan mayat, binatang, oral seks, anal seks, lesbian dan homoseksual. Dalam konteks pornografi, dari undang-undang ini dapat dipahami mindset dan pandangan pembuat hukum, serta pandangan mayoritas masyarakat Indonesia terhadap homoseksualitas. LGBT secara luas masih dipandang sebagai ketidakwajaran. Anomaly ditengah-tengah masyarakat.

Selain dalam Undang-Undang terdapat juga sekurang-kurangnya terdapat lima
Peraturan Daerah (Perda) yang mengklasifikasikan homoseksualitas sebagai tindakan yang melanggar Peraturan Daerah setempat:

1) Perda Provinsi tentang Pemberantasan Maksiat (No. 13/2002) di Provinsi Sumatera Selatan. Perda ini menggolongkan perilaku homoseksual dan anal seks oleh laki-laki (tanpa menyebutkan apakah bersifat penetratif atau menerima) sebagai perbuatan tidak bermoral, sebagaimana halnya prostitusi, perzinahan, perjudian dan konsumsi minuman beralkohol.

2) Perda Kota tentang Pemberantasan Pelacuran (No. 2/2004) di Palembang, ibukota Provinsi Sumatera Selatan. Perda ini serupa dengan Perda Provinsi, hanya menggunakan istilah "pelacuran" dan bukan "maksiat."

3) Perda Kabupaten tentang Ketertiban Masyarakat (No. 10/2007) di Banjar, Provinsi Kalimantan Selatan. Perda ini dalam definisinya tentang "pelacur" menyebutkan perbuatan homoseksual dan heteroseksual yang "tidak normal" (di samping perbuatan yang "normal"). Tidak ada penjelasan tentang apa yang merupakan perbuatan "normal" atau "tidak normal." Perda ini juga melarang pembentukan organisasi "yang mengarah kepada perbuataan asusila" yang "tidak bisa diterima oleh budaya masyarakat [setempat]." Hal ini kemudian dijelaskan 
dengan menyebutkan contoh organisasi lesbian dan gay "dan sejenisnya."

4) Perda Kota tentang Pembangunan Tata Nilai Kehidupan Kemasyarakatan Yang Berlandaskan Pada Ajaran Agama Islam dan Norma-Norma Sosial Masyarakat (No. 12/2009), di Tasikmalaya, Jawa Barat. Perda ini melarang perzinahan dan pelacuran, baik heteroseksual maupun homoseksual.

5) Perda Kota tentang Pencegahan, Pemberantasan dan Penindakan Penyakit Sosial (No. 9/2010) di Padang Panjang, Sumatera Barat. Bagian definisi istilah secara tegas menyebutkan hubungan "homoseksual dan lesbian" dan selanjutnya melarang hubungan tersebut serta melarang orang yang "menawarkan diri untuk terlibat dalam hubungan homoseksual maupun lesbian, baik dengan atau tanpa menerima upah."15

Melihat dengan cermat beberapa UndangUndang serta Perda diatas, dapat diketahui bahwa sejauh ini didalam undang-undang sendiri tidak ada upaya kriminalisasi terhadap kelompok LGBT dan kelompok interseksual lainnya. Setidaknya tidak secara explicit. Namun yang dapat dilihat secara jelas adalah tidak adanya bentuk akomodasi apapun terhadap hak-hak dari kelompok LGBT. Ditambah lagi beberapa Peraturan Daerah yang meskipun tidak mengungkapkan secara terang, namun pada dasarnya mengkriminalisasi kelompok LGBT. Bahkan pada titik ekstrim Homoseksual diklasifikasikan tidak bermoral. Hal ini semakin menunjukan betapa lemahnya kelompok lesbian dan gay dimata hukum. Perhatikan juga bahwa dalam rumusan peraturan-peraturan diatas, hanya ada dua klasifikasi gender yang disebutkan, yaitu lakilaki dan perempuan. Tidak berarti bahwa kelompok transgender tidak mengalami ketimpangan. Justru sebaliknya, hal ini mengindikasikan tidak adanya pengakuan sama sekali di mata hukum untuk kelompok transgender. Berakibat pada sulitnya kelompok ini untuk mendapat pelayanan administratif.

Permasalahan melebar ketika perilaku LGBT dihubungkan dengan hak-hak lainnya sebagaimana rilis yang dimuat Komnas HAM pada 4 Februari 2016. Secara mutakhir, rilis Komnas HAM tersebut merujuk pada PrinsipPrinsip Yogyakarta (The Yogyakarta Principles) Tahun 2006 dan Peraturan Menteri Sosial No. 8 Tahun 2012 tentang Pendataan dan Pengelolaan Data Penyandang Masalah Kesejahteraan Sosial dan Potensi dan Sumber Kesejahteraan Sosial (Permen $8 / 2012$ ). Permen $8 / 2012$, menerangkan bahwa LGBT adalah komunitas yang diakui oleh

15 Ibid. hlm. 24-25. 
negara. Permen 8/2012 bukan dalam preferensi pembelaan tapi perlindungan. Hal paling penting ialah bahwa Permen 8/2012 diperuntukkan bagi operasional pendataan dan pengelolaan data penyandang masalah sosial. ${ }^{16}$

Bentuk perlindungan terhadap kelompok LGBT secara terbatas ada dalam UndangUndang Dasar 1945 dan Undang-Undang Nomor 39 Tahun 1999 tentang Hak Asasi Manusia. Undang-Undang Dasar 1945 BAB XA, pasal 28A sampai dengan pasal 28J mengatur tiap-tiap hak dasar yang berhak diperoleh oleh "setiap orang”. Demikian juga Undang-Undang Nomor 39 Tahun 1999 tentang Hak Asasi Manusia, dimana setiap hak-hak yang diatur didalamnya berlaku untuk setiap orang. Terlebih lagi, kedua undang-undang ini mengatur agar setiap orang terbebas dari diskriminasi dalam bentuk apapun. Namun pada kenyataannya, tidak mendapatkan hak-hak mereka sebagaimana mestinya. Berbagai upaya untuk mewujudkan advokasi bagi kelompok LGBT juga belum membuahkan hasil yang diharapkan. Pemerintah dan juga aparat keamanan gagal untuk menjamin keamanan kaum LGBT, serta gagal melindungi hak kebebasan untuk berserikat kelompok LGBT. Terbukti dengan berbagai serangan dari kelompok garis keras terhadap kegiatan-kegiatan yang diselenggarakan kelompok LGBT.
Tanpa dukungan penuh dari pemerintah, keadilan terhadap kaum LGBT akan sulit untuk terealisasikan. Berbagai upaya dapat terus dilakukan oleh organisasi dan aktivis LGBT, namun sekali lagi, tanpa dukungan dari pemerintah, tidak akan ada hasil yang dicapai. Karena itulah pemerintah sebagai pengambil dan pembentuk kebijakan perlu lebih memperhatikan hak-hak dan kewajiban kelompok LGBT dalam kebijakankebijakannya. Diperlukan juga suatu undangundang untuk menjamin terpenuhinya hak dan kewajiban tersebut, serta melindungi kelompok LGBT dari berbagai tindakan diskriminatif yang berusaha melanggar hakhak mereka. Pemerintah juga perlu memfasilitasi dan menjamin kebebasan kelompok LGBT untuk mengekspresikan kebebasan berserikat dan beraspirasi. Pada akhirnya, Pemerintah dan segenap perangkatnya perlu mengerahkan seluruh kemampuannya dalam kapasitasnya, demi terwujudnya keadilan bagi seluruh masyarakat Indonesia, termasuk kelompok LGBT. sebagaimana yang telah dicita-citakan dalam Pancasila.

Menurut Manfred Nowak, bentuk perlindungan negara memiliki dua dimensi yaitu dimensi preventif dan remedial. Dimensi preventif dijelaskan dalam Pasal 2 ayat (2) ICCPR yang mewajibkan negara anggota untuk melakukan untuk standarisasi legislatif

16 Mira Fajri, 2016, LGBT dalam Perspektif Hukum di Indonesia, https://www.republika.co.id, diakses pada tanggal 2 Juni 2019. 
peraturan nasional agar sesuai dan searah dengan ketentuan dalam ICCPR. Kewajiban tersebut harus disesuaikan pula dengan kebutuhan dari hak terkait. Dimensi perlindungan hak yang kedua adalah dimensi remedial yang menjelaskan bahwa ketika terjadi pelanggaran terhadap suatu hak asasi manusia maka negara anggota memiliki kewajiban untuk memberikan akses atas bantuan kepada korban pelanggaran. Dimensi remedial dalam ICCPR ditunjukan dalam ketentuan Pasal 2 ayat (3) ICCPR. Paragraf 15 Komentar Umum Nomor 31. ${ }^{17}$

Kajian hukum tidak hanya tentang norma hukum positif tapi juga sejarah hukum dan politik hukum yang berada dalam taraf pembangunan hukum, penegakan hukum, dan pengawasan hukum. Hal ini diperpanjang dengan fakta adanya kekosongan hukum, interpretasi hukum, norma hukum yang kabur, saling tumpang tindih atau bahkan saling bertentangan. Sehingga, selalu ada ruang bagi gagasan atau perilaku apapun, baik yang tidak masuk akal sekalipun, untuk terus eksis di kancah kajian atau pendapat hukum. Inilah suatu logical plot yang dikenal dengan istilah democratic and constitutional welfare state sebagai muatan glosarium ketatanegaraan Indonesia. ${ }^{18}$ Oleh karena itu, di masa akan datang diharapkan perlindungan hukum terhadap kaum LGBT tidak melanggar konvensi internasional berkaitan dengan HAM

\section{KESIMPULAN}

Kaum LGBT, terlepas dari orientasi seksual dan identitas gender, adalah manusia sama seperti komponen masyarakat lainnya, dan karenanya memiliki Hak Asasi yang tidak boleh dicabut dari mereka, dan tidak boleh dilanggar dalam bentuk dan alasan apapun. Berkaca dari kenyataan yang terjadi saat ini di Indonesia, dan juga kenyataan di berbagai pelosok dunia, dimana kaum LGBT masih mengalami berbagai bentuk diskriminasi, mulai dari tindakan kekerasan sampai dengan regulasi hukum yang diskriminatif, pemerintah Indonesia perlu meningkatkan lagi usahanya dalam mewujudkan keadilan bagi seluruh rakyatnya, terutama kaum LGBT. Upaya tersebut bisa dalam bentuk kebijakan, maupun peraturan perundangundangan yang fokusnya adalah hak dan kewajiban kaum LGBT.

\section{DAFTAR PUSTAKA}

\section{Peraturan Perundang-undangan}

Undang-Undang Nomor 1 Tahun 1974 tentang Perkawinan

Kitab Undang-Undang Hukum Pidana (KUHP), Pasal 284, 285, 292

\footnotetext{
17 Manfred Nowak, et al. 2016. Human Rights: A Handbook for Parliamentarians. Geneva: Inter-Parliamentary Union and United Nations (Office of the High Commissioner for Human Rights). hlm. 33.

18 Mira Fajri, Loc. Cit.
} 
Undang-Undang Nomor 23 Tahun 2006, tentang Administrasi Kependudukan

Undang-Undang Nomor 44 Tahun 2008 tentang Pornografi

Undang-Undang Dasar (UUD) Negara Kesatuan Republik Indonesia Tahun 1945

Undang-Undang Nomor 39 Tahun 1999 tentang Hak Asasi Manusia

Peraturan Menteri Sosial No. 8 Tahun 2012 tentang Pendataan dan Pengelolaan Data Penyandang Masalah Kesejahteraan Sosial dan Potensi dan Sumber Kesejahteraan Sosial

\section{Buku}

Budiarjo, Miriam. (2008). "Dasar-Dasar Ilmu Politik". Jakarta. Gramedia Pustaka Utama

Nowak, Manfred et al. (2016). Human Rights: A Handbook for Parliamentarians. Geneva: Inter-Parliamentary Union and United Nations (Office of the High Commissioner for Human Rights).

Wahidin, Samsul. (2015). "Dasar-Dasar Pendidikan Pancasila dan Pendidikan Kewarganegaraan”. Yogyakarta. Pustaka Pelajar.

\section{Laporan dan Jurnal}

Swain, Keith W. 21 Juni 2007. "Gay Pride Needs New Direction". Denver Post."Free \& Equal Campaign Fact Sheet: Intersex". United Nations Office of the High Commissioner for Human Rights. 2015.
"Discriminatory laws and practices and acts of violence against individuals based on their sexual orientation and gender identity". United Nations High Commissioner for Human Rights. 2011

Yulianti Muthmainnah. 2016. "LGBT Human Rights in National Policies". Indonesian Feminist Journal. Vol. 4, No. 1

Meilanny Budiarti Santoso. 2016. "LGBT dalam perspektif Hak Asasi Manusia" Staf Pengajar Departemen Kesejahteraan Sosial - Universitas Padjadjaran. Vol. 6 No. 2

Dédé Oetomo dan Khanis Suvianita. 2014. "Hidup sebagai LGBT di Asia: Laporan Nasional Indonesia". Komunitas Nasional LGBT Indonesia.

\section{Internet}

http://nasional.kompas.com/read/2017/05/18/ 12310041/icjr.nilai.hukum.cambuk.pas angan.lgbt.di.aceh.diskriminatif.

"Special Report: Indonesia - Exchanging pluralism for an Islamic state" http://pancasilaislam. blogspot.sg/2012/10/special-reportindonesia-exchanging.html.

https://nasional.tempo.co/read/650564/muikeluarkan-fatwa-hukum-mati-kaumhomoseksual.

https://en.wikipedia.org/wiki/Charles_W._So carides

Mira Fajri, 2016, LGBT dalam Perspektif Hukum di Indonesia, https://www.republika.co.id, diakses pada tanggal 2 Juni 2019. 